\title{
Archipel
}

ARCHIPEL Études interdisciplinaires sur le monde insulindien

$96 \mid 2018$

Varia

Suma Oriental, by Tomé Pires, edited by Rui Manuel Loureiro. Lisbon: Centro Científico e Cultural de Macau and Fundação Jorge Álvares; Macau: Fundação Macau, 2017, 335 pages, bibl., index. ISBN 978-972-8586-52-2.

\section{Roderich Ptak}

\section{OpenEdition}

\section{Electronic version}

URL: http://journals.openedition.org/archipel/858

DOI: $10.4000 /$ archipel. 858

ISSN: 2104-3655

\section{Publisher}

Association Archipel

\section{Printed version}

Date of publication: 15 November 2018

Number of pages: $176-179$

ISBN: 978-2-910513-80-1

ISSN: 0044-8613

\section{Electronic reference}

Roderich Ptak, «Suma Oriental, by Tomé Pires, edited by Rui Manuel Loureiro. Lisbon: Centro Científico e Cultural de Macau and Fundação Jorge Álvares; Macau: Fundação Macau, 2017, 335 pages, bibl., index. ISBN 978-972-8586-52-2. », Archipel [Online], 96 | 2018, Online since 20 November 2015,

connection on 23 November 2020. URL : http://journals.openedition.org/archipel/858 ; DOI : https:// doi.org/10.4000/archipel.858 
serve many needs. This is why the present book is an important item that should be acquired by scholars working in different branches of history.

RODERICH PTAK

Suma Oriental, by Tomé Pires, edited by Rui Manuel Loureiro. Lisbon: Centro Científico e Cultural de Macau and Fundação Jorge Álvares; Macau: Fundação Macau, 2017, 335 pages, bibl., index. ISBN 978-972-8586-52-2.

Historians of maritime Asia, and especially of Southeast Asia, are most familiar with the Suma Oriental by Tomé Pires (c. 1470 - c. 1527). Pires' book is a key source for our understanding of how commercial exchange within the large space that extends from Egypt to the coasts of China was functioning during the late medieval period and at the time when the Portuguese took hold of such coastal locations as Goa and Melaka. Besides recording trade goods and the flow of commodities, Pires also tells us something on different ethnic groups, local customs, rulers and institutions, geographical settings, trade routes, and many other phenomena. Furthermore, as is well known, the Suma Oriental constituted the basis for several modern works on maritime Asia; the monumental account by Vitorino Magalhães Godinho and the study by M.A.P. Meilink-Roelofsz, to mention just two examples, heavily rely on the observations made by Pires.

Today, there are three versions of the Suma Oriental. (1) The longest version is a manuscript source in the Bibliothèque de l'Assemblée Nationale, Paris. In 1944, Armando Cortesão published this text for the Hakluyt Society; since then it has been cited in thousands of books and articles. This edition, in two volumes, contains an English translation of the text, with copious notes, and the Portuguese "original" itself. In 1978, the latter also appeared in Coimbra, as part of the series "Acta Universitatis Conimbrigensis", and again with many notes. Both the two volumes issued for the Hakluyt Society and the Coimbra monograph also include the so-called book of Francisco Rodrigues, conserved together with the Suma Oriental. (2) The second version, found in Lisbon, is much shorter; indeed, several parts are missing. An annotated edition of that manuscript, prepared by Rui Manuel Loureiro, came out under the title $O$ manuscrito de Lisboa da "Suma Oriental" de Tomé Pires (Contribuição para uma edição crítica) in the series "Memória do Oriente," published by the Institvto Portvgvês do Oriente, Macau, 1996. (3) A third copy reached Italy already in the late $1520 \mathrm{~s}$. Shortly thereafter, in the mid-sixteenth century, an Italian translation of this text appeared in Giovanni Battista Ramusio's collection Navigationi $e$ Viaggi. Today the Ramusio version, which is also shorter than the one in Paris, is accessible, for example, through the edition by Marcia Milanesi (6 vols; Torino: Einaudi, 1978-1988).

The transmission of Pires' manuscript from Asia to Europe and its circulation inside Europe was, of course, a complex affair as shall be explained below. Historians have made some efforts to reconstruct the Suma Oriental's trajectory through time but many 
details remain unknown. The introductory parts to items (1) and (2), in particular, contain useful information on all this. That also applies to the book under review here, which includes an even more advanced article on Pires' account, its different versions, and some of the persons (possibly) involved in its early uses and circulation.

What, in fact, is Loureiro's new book about? - It is an annotated edition of the Paris manuscript, in full length, but without translations. Several considerations encouraged Loureiro to prepare his work: (a) Cortesão's presentations, we learn from Loureiro's long introduction, contain some doubtful readings. Clearly, this has to do with the fact that many passages in the Paris manuscript are extremely difficult to decipher. Loureiro, who is an experienced editor of handwritten documents, and especially of sixteenth century-manuscripts, suggests several new interpretations of single words, names or even entire phrases. (b) Secondly, he decided to improve the "graphical" presentation of the text. The original contains a large number of abbreviations, as well as many unnecessary capital initials at the beginning of words, occasionally even in the middle of certain expressions. Above all, there are practically no punctuation marks. Cortesão, in his modern Portuguese editions of the manuscript, has tried to follow the original in these regards as closely as possible; needless to state, this makes it very difficult to understand the printed Portuguese texts. Loureiro disentangled all the abbreviations, adding commas and full stops, and he also standardized many other things, for example recurrent variations between individual letters, especially $\mathrm{i} / \mathrm{j}, \mathrm{u} / \mathrm{v}$ and $\mathrm{c} / \mathrm{c}$, while maintaining all ancient spellings that pose no major problem to modern users. (c) Furthermore, occasionally Loureiro refers to the Lisbon manuscript in his notes, thus offering comparisons between both extant Portuguese versions. This is very helpful because in a number of cases the Lisbon version is definitely much easier to understand. (d) A fourth point concerns the internal arrangement of the Paris manuscript. Ages ago, when the manuscript went to the bookbinder, the latter somehow messed up the logical sequence of the extant folios. Cortesão, trying to be faithful to his source, maintained the confused sequence for the Portuguese parts of his editions, while altering it for the English translation. Naturally, this has caused some irritation, especially with regard to the segments dealing with China. Thus, while the Paris manuscript spreads these parts over two different sections, unduly separated from each other through the descriptions of other locations, Loureiro has rejoined the Chinese chapters in a single block (livro IV). A second example concerns the short part on Sri Lanka. In the original manuscript the relevant entry appears after the section on Sumatra / Moluccan Islands; in Loureiro's edition (just as in Cortesão's English translation) the Sri Lankan "chapter" precedes the segments on Bengal, which makes more sense. - Loureiro's new book, one may add, contains a very useful table (on p. 291) which summarizes the segmentation of the Paris manuscript and the segmentations adopted in its published versions. These and other formal points suggest that Loureiro's edition will make it definitely much easier now to also make efficient use of Pires' Portuguese text, side by side with Cortesão's celebrated English translation.

Already in his introduction to the Lisbon version, Loureiro pointed out that the extant Paris manuscript should be a copy of an earlier version, close to the original text. The latter, so it seems, is now lost. In the introduction to the present book, he adds that the Paris copy was probably made by Francisco Rodrigues (see pp. 33, 34), who had met Pires in India. Earlier, Cortesão had already expressed a similar view. 
The full title of the Paris version, in Loureiro's reading (p. 55), is Somma orientall que trata do maar Roxo athee os chĩs copilada por Thome Pirez (Pires' name appears as $\mathrm{Piz}$ ). The Lisbon manuscript, again following Loureiro's transcription, bears the title Soma horiemtall que trata do mar Roxo ate os chims (see item 2, above, p. 57). The divergent spellings are remarkable indeed, as this example shows. One may attribute these differences to the assumption that neither of these two texts is identical with the earliest manuscript(s) now lost.

Loureiro thinks that there were four such original copies. (1) One copy, offered to the Portuguese king, remained in the royal library until the mid-eighteenth century. (2) A further copy, originally owned by Afonso de Albuquerque, apparently reached Brás de Albuquerque, Afonso's son. Possibly, it later formed the basis for an abbreviated version, which in turn served as the starting-point for Ramusio's translation and the extant Lisbon text. (3) A third copy was in Pires' hands. Presumably, Pires died in China and one does not know what happened to this text. (4) The fourth copy was the one used by Francisco Rodrigues. - Some of these observations derive from references to Pires' work in other early material. They make it quite clear that a reconstruction of the original text is no longer possible; one could at best verify the shape of certain words and sentences, or perhaps some paragraphs, but many parts of the text would remain open to divergent philological views.

However, historians dealing with maritime Asia's past may not be too interested in philological trifles and the difficulties of defining the correct spelling of certain words and terms. Rather, what counts more is the rich factual data contained in the book. The parts on Melaka, Sumatra and Java in particular are of great importance for studies related to maritime Southeast Asia. Besides that, the Chinese sections have also attracted much interest. There is a recent work - Pascale Girard et al. (introduction, translations), Prisonniers de l'Empire Céleste. Le désastre de la première ambassade portugaise en Chine (1517-1524) (Paris: Chandeigne, 2013) - which makes use of these sections. The French translation (by João Vieigas) of the relevant passages contain various notes which combine evidence drawn from Chinese sources and early European material to explain some of the descriptive elements found in Pires' account. Although this is an excellent book, many points still pose questions, for example Pires' references to the garments and footwear then used in China. Similar problems pertain to many other segments of the Suma Oriental. Therefore, Loureiro is quite right when alluding to the necessity of initiating more research on this text.

Another point briefly addressed by him concerns the sources used by Pires. The accounts by Marco Polo and John de Mandeville are two candidates. Evidently, Pires was also familiar with mythology. Finally, he probably had access to some local texts, possibly even including an early predecessor of the Sejarah Melayu, if one follows Loureiro's suggestion (p. 30). However, nothing is certain. Again, we need further research on these and similar issues, just as on the question to what extent Pires had deliberately emphasized, exaggerated or even falsified certain things. Historians have addressed this concern on some occasions, but never in a systematic way. Recently Jorge M. dos Santos Alves suggested that Pires, while staying in Melaka, received information through some of the merchants associated with the Melaka-Brunei-Luzon trade axis; at the same time, he probably was in touch with Javanese informants. More specifically, one of Alves' assumptions is that the image of China as a military 
weakling (see Loureiro, pp. 150, 155) could go back to Javanese (and Malay) "propaganda" ultimately accepted by Pires for whatever reason (see Alves' article in Francisco Roque de Oliveira, Percepções europeias da China dos séculos XVI a XVIII. Ideias e imagens na origem da moderna Sinologia [Lisbon: Centro de Estudos Geográficos da Universidade de Lisboa; [Mafra:] Palácio Nacional de Mafra, 2017]). Needless to state, such ideas are apt to pave the way for fresh investigation.

To round off my remarks: Loureiro's presentation of the Paris manuscript - jointly with his work on the Lisbon version - will help us to gain a better understanding of the Suma Oriental. The punctuation of the text itself greatly facilitates its reading. The technical arrangement is straightforward and very clear. The notes are not as copious and complex as the bulky comments prepared by Cortesão; rather, Loureiro has limited his explanations to essential observations. Moreover, unlike Cortesão he gives no references to secondary sources in the notes. There is a simple reason for this: Experts are familiar with the relevant material anyway; also, secondary works abound and one can hardly consider all possible sources in each case. Put differently, Loureiro's book does not push readers into a philological labyrinth; it is arranged in such a way that both specialists and historians with general interests will be able to digest Pires' account. Finally, the introduction is very informative and contains a well-balanced bibliography. There is also a detailed and reliable index at the end of the book. In sum: Libraries and historians dealing with maritime Asia ought to acquire this item for their collections.

RODERICH PTAK

Sher Banu A.L. Khan, Sovereign Women in a Muslim Kingdom: The Sultanahs of Aceh, 1641-1699. Singapore, NUS Press, National University of Singapore, 2017, 318 p., gloss., bibl. index. ISBN 978-981-4722-20-9

Sher Banu A.L. Khan, assistant professor at the Malay Studies Department, National University of Singapore, begins by pointing out that although the reigns of the four sultanah of Aceh, ranging from 1641 to 1699 (Sultanah Tajul Alam Safiatuddin Syah - r. 1641-1675, Sultanah Nur Alam Naqiatuddin Syah - r. 1675-1678, Sultanah Inayat Zakiatuddin Syah - r. 1678-1688, Sultanah Kamalat Zainatuddin Syah, r. 16881699), have been amply commented upon, so far this period has never been the focus of an in-depth study devoted to the origin, nature and impact of these reigns. Yet the contrast between nineteenth and twentieth centuries scholarly opinions on the one hand - neutral at best-, and a number of contemporary positive comments on these reigns on the other hand, raises numerous questions, in particular regarding the socioeconomic context in 1641, the reasons leading to an unprecedented succession of four sultanahs, the authority of each in relation to Islam and adat, how they related to a predominantly male economic and political elite, their diplomatic roles and strategies, as well as the reasons which led to the interruption of the experience in 1699. 